\title{
Design of a DNA-based shift register
}

\author{
Christy M Gearheart ${ }^{1}$, Eric C Rouchka* ${ }^{*}$, Benjamin Arazi \\ From UT-ORNL-KBRIN Bioinformatics Summit 2010 \\ Cadiz, KY, USA. 19-21 March 2010
}

\section{Background}

DNA-based circuit design is an area of research in which traditional silicon-based technologies are replaced by naturally occurring phenomena taken from biochemistry and molecular biology. This research focuses on further developing DNA-based methodologies to mimic digital data manipulation, demonstrating how information can be parsed through a digital circuit comprised of DNA-based logic gates.

\section{Results and conclusion}

A novel logic gate design based on chemical reactions is presented in which observance of double stranded sequences indicates a truth evaluation. Circuits are obfuscated by removing of physical sequence connections, allowing client-specific representative strands for input sequences, altering the input sequence strands over time, and varying the input sequence length. Shifting along the input stream to parse individual inputs is accomplished through simulated alternative splicing of DNA sequences stored in plasmid vectors.

\section{Acknowledgements}

C. M. Gearheart would like to thank Hank and Becky Conn for their continued support. This work was supported in part by NIH-NCRR Grant P20RR16481 and NIH-NIEHS Grant P30ES014443. Its contents are solely the responsibility of the authors and do not represent the official views of NCRR, NIEHS, or NIH.

\section{Author details}

'Department of Computer Engineering and Computer Science, University of Louisville, Louisville, KY 40292, USA. ²Department of Electrical and Computer Engineering, Ben-Gurion University, POB 653 Beer-Sheva 84105, Israel.

Published: 23 July 2010

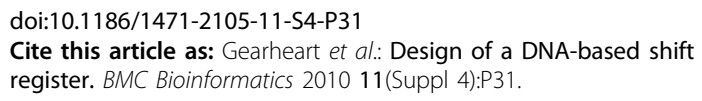

* Correspondence: eric.rouchka@louisville.edu

'Department of Computer Engineering and Computer Science, University of Louisville, Louisville, KY 40292, USA
Submit your next manuscript to BioMed Central and take full advantage of:

- Convenient online submission

- Thorough peer review

- No space constraints or color figure charges

- Immediate publication on acceptance

- Inclusion in PubMed, CAS, Scopus and Google Scholar

- Research which is freely available for redistribution

Submit your manuscript at www.biomedcentral.com/submit
C Biomed Central 